\title{
IMPLEMENTASI COLLABORATIVE STRATEGIC READING UNTUK MENINGKATKAN KEMAMPUAN MEMBACA PEMAHAMAN EVALUATIF DAN APRESIATIF MAHASISWA
}

\author{
Afnita \\ athailah.afif@yahoo.co.id \\ Universitas Negeri Padang
}

Penelitian ini dilatarbelakangi oleh keterbatasan kemampaun membaca pemahaman evaluative dan apresiatif mahasiswa STKIP PGRI Sumatera Barat. Tujuan penelitian ini untuk mengetahui hasil kemampuan membaca evaluatif dan aptresiatif mahasiswa yang diajarkan melalui Collaborative Strategic Reading (CSR). Jenis penelitian ini adalah penelitian tindakan dengan mengikuti prosedur kerja model Kemmis \& MC Taggart yang meliputi empat tahapan pokok per siklus, yaitu (1) perencanaan, (2) tindakan, (3) pengamatan, dan (4) refleksi. Hasil penelitian menunjukkan bahwa kemampuan membaca pemahaman evaluatif mahasiswa meningkat. Nilai rata-rata pada pratindakan 47,8 naik menjadi 60,3 pada siklus pertama, dan 71,8 pada siklus kedua. Hal ini mengalami peningkatan sebesar $24 \%$. Untuk pemahaman apresiatif juga mengalami peningkatan. Pada pratindakan nilai rata-ratanya 41,9 naik menjadi 53,4 pada siklus pertama dan naik lagi menjadi 66 pada siklus kedua. Kenaikan untuk dimensi ini mencapai $24,1 \%$. Dapat disimpulkan bahwa proses memahami bacaan mahasiswa menjadi lebih optimal serta kemampuan membaca avaluatif dan apresiatif mahasiswa meningkat setelah diterapkannya Collaborative Strategic Reading (CSR). Dengan demikian, strategi ini bias menjadi alternatif dalam pembelajaran membaca, khususnya dalam meningkatkan kemampuan membaca pemahaman evaluative dan apresiatif.

Kata kunci: Collaborative Strategic Reading, membaca pemahaman, evaluatif, apresiatif.

\section{PENDAHULUAN}

"Membaca adalah jendela dunia." Dengan membaca, orang akan menjadi kaya pengetahuan dan mampu mendalami pengetahuannya itu. Pendidikan mustahil bisa dijalankan tanpa membaca. Smith (1999:12) menyatakan bahwa membaca merupakan suatu proses yang dilakukan pembaca untuk memperoleh pesan atau informasi dari teks yang dibacanya. Dalam proses tersebut pembaca berusaha merekonstruksi pesan yang ada dalam teks. Pada kegiatan membaca terjadi proses pengolahan informasi masukan yang terdiri atas informasi visual dan informasi nonvisual. Demikian juga Nuttal (1989:2) menjelaskan bahwa membaca sesungguhnya merupakan proses berpikir yang 
tergantung pada proses rasionalisasi atas apa yang dibaca, suatu proses yang mengandung pola-pola berpikir, aturan dan hukum, analisa, sebab akibat, pemecahan masalah, dan bukan sekedar aktivitas penglihatan yang hanya sampai pada pengenalan rumus atau lambang tertulis dan memahami maknanya. Selanjutnya, Walker (1992:4) menyebutkan:

"Reading is an interactive prosess in which readers shift between sources of information (What they know and what the text say), elaborate meaning and strategies, check their interpretation (revising when appropriate), and use the setting to focus their interpretation."

Ini menunjukkan bahwa membaca tidak hanya sekedar menarik informasi yang didapat dari sebuah teks yang tersaji, lebih jauh dari itu membaca merupakan proses yang terjadi dua arah, yang mana pembaca memadukan antara sumber informasi, makna, dan strategi bahan bacaan dengan penafsiran bahan bacaan yang diketahui oleh pembaca tersebut.

Dalam membaca, kemampuan dalam memahami teks merupakan hal yang penting.Dengan kemampuan ini seseorang dapat dengan mudah mengambil makna, menarik informasi dari bacaan yang tersaji dan menerima serta memadukan informasi yang didapat dengan pengetahuan sebelumnya (prior knowledge). Dalam kaitannya dengan pemahaman bacaan dalam bentuk teks, proses pemahaman membaca sebuah teks tidak hanya dinilai sebagai sebuah transformasi simbol-simbol teks pada bacaan tertentu melainkan sebuah proses transformasi keilmuan dengan membuat suatu sintesis, menarik kesimpulan, dan juga membuat interpretasi dari teks yang disajikan sebagai bahan bacaan tersebut. Pemahaman bacaan jenis ini termasuk membaca pemahaman tingkat evaluatif dan apresiatif.

Pemahaman evaluative terkait dengan pemahaman isi bacaan yang dilakukan pembaca dengan berpikir secara kritis dengan mengungkapkan pendapat dan penilaiannya terhadap isi bacaan. Selanjutnya, pemahaman apresiatif berkaitan dengan pemahaman terhadap bacaan yang dilakukan dengan kegiatan membaca melalui berpikir 
secara kritis dan interpretative untuk memperoleh pandangan dan gagasan baru serta pemikiran yang orisinal.

Paparan di atas menjelaskan betapa pentingnya kemampuan mahasiswa dalam memahami bacaan, karena membaca menjadi kunci ilmu pengetahuan, bahkan kunci sukses studi bagi mahasiswa. Namun kenyataannya, kemampuan memahami bacaan itu belum dimiliki secara baik oleh mahasiswa angkatan 2014 di Program Studi Pendidikan Bahasa dan Sastra Indonesia Sekolah Tinggi Keguruan dan Ilmu Pendidikan (STKIP) PGRI Sumatera Barat.

Dari hasil pretes yang diberikan sebelum pelaksanaan tindakan, secara umum menunjukan bahwa dari 32 orang peserta kuliah, umumnya peserta kuliah belum mampu dengan baik menangkap makna yang terkandung dalam sebuah bacaan baik makna yang tersurat maupun makna yang tersirat. Dengan demikian, dapat disimpulkan bahwa kemampuan mahasiswa dalam memahami bacaan tergolong rendah. Setelah diadakan diskusi yang membahas hasil observasi awal dan berdasarkan hasil pretes kemampuan memahami bacaan mahasiswa, maka didapatkan fakta-akta yang ada, di antaranya adalah (1) dosen belum menerapkan metode atau strategi pembelajaran yang sesuai dengan kebutuhan mahasiswa, bahkan cenderung menggunakan metode pembelajaran yang konvensional, tidak jelas, dan tidak menarik. Langkah-langkah yang dilakukan selama proses pembelajaran kurang terorganisir dengan baik dan tidak efektif. (2) Akibat kurang terorganisirnya langkah-langkah pembelajaran yang diterapkan oleh dosen, maka sebagian besar mahasiswa belum menunjukan keseriusan dan partisipasi aktifnya dalam proses pembelajaran membaca terutama memahami bacaan. (3) Berdasarkan hasil pretes yang telah dilaksanakan sebelum tindakan, maka kemampuan awal memahami bacaan mahasiswa yang belum mencapai kriteria ketuntasan belajar adalah pada aspek kemampuan pemahaman evaluatif dan pemahaman apresiatif.

Dalam kondisi seperti ini, perlu dilakukan upaya peningkatan kualitas proses pembelajaran membaca untuk meningkatkan kemampuan mahasiswa dalam memahami bacaan. Salah satu cara yang dapat dilakukan untuk meningkatkan kualitas proses pembelajaran membaca serta capaian hasil belajar/kemampuan memahami bacaan 
adalah melalui perbaikan metode atau strategi pembelajaran. Strategi yang digunakan adalah strategi membaca kolaboratif atau Collaborative Strategic Reading (CSR).Grabe (2009:205) menyatakan collaborative strategic reading merupakan salah satu strategi yang mengombinasikan antara pemahaman membaca (reading comprehension) dan pembelajaran bersama (cooperative learning).

Dengan penerapan strategi membaca kolaboratif ini diharapkan kemampuan mahasiswa dalam memahami bacaan akan meningkat. Hal ini dimungkinkan karena strategi membaca kolaboratif ini bertujuan untuk: (1) memaksimalkan proses kerjasama yang berlangsung secara alamiah di antara para peserta didik; (2) memberi kesempatan kepada peserta didik menjadi partisipan aktif dalam proses pembelajaran; (3) menciptakan lingkungan pembelajaran yang berpusat pada siswa, kontekstual, dan terintegrasi; (4) mengembangkan berpikir kritis dan keterampilan memecahkan masalah; dan (5) menumbuhkan rasa tanggung jawab karena masing-masing peserta didik bertanggung jawab terhadap tugas yang telah disepakati.

Berdasarkan latar belakang masalah yang telah dikemukakan sebelumnya, maka rumusan masalah penelitian ini adalah (1) Bagaimanakah proses peningkatan kemampuan memahami bacaan mahasiswa melalui strategi membaca kolaboratif atau Collaborative Strategic Reading? (2) Apakah kemampuan memahami bacaan mahasiswa dapat ditingkatkan melalui strategi membaca kolaboratif atau Collaborative Strategic Reading? Adapun tujuan penelitian ini adalah untuk memperoleh pemahaman yang mendalam tentang proses pembelajaran dan mengetahui hasil kemampuan memahami bacaan mahasiswa yang diajarkan melalui strategi membaca kolaboratif.

\section{METODE}

Penelitian ini merupakan penelitian tindakan (action research) yang dilaksanakan di Program Studi Pendidikan Bahasa dan Sastra Indonesia Sekolah Tinggi Keguruan Ilmu Pendidikan (STKIP) PGRI Sumatera Barat. Prosedur kerja dalam penelitian ini menggunakan model tindakan siklus yang diusulkan oleh Kemmis dan McTaggart (1994:23), yang meliputi empat tahapan pokok per siklus, yaitu (1) 
perencanaan, (2) tindakan, (3) pengamatan, dan (4) refleksi. Data penelitian terdiri atas data kualitatif dan data kuantitatif. Data kualitatif mencakup segala informasi berkenaan dengan penerapan strategi membaca kolaboratif pada pembelajaran membaca. Data pembelajaran memuat tentang tindakan/aktivitas peneliti (dosen) dan mahasiswa serta tanggapan mahasiswa dalam pembelajaran dengan menggunakan strategi membaca kolaboratif. Data tanggapan mahasiswa menyangkut perasaan dan sikapnya saat melaksanakan pembelajaran. Data kuantitatif dalam penelitan ini adalah data yang menyangkut hasil tes kemampuan memahami bacaan mahasiswa. Data kualitatif dihimpun melalui observasi, catatan harian/diary, wawancara, sedangkan data kuantitatif dihimpun melalui tes.

Data kualitatif dianalisis dengan menggunakan analisis data kualitatif, yaitu dengan cara mengklasifikasikan, mencari pola, menemukan kecenderungankecenderungan, dan mengorganisasikan data/informasi dalam bentuk paparan naratif atau pendeskripsian dan representasi grafis. Data kuantitatif dianalisis dengan statistika deskriptif yang meliputi mean (rerata), distribusi frekuensi, dan persentase. Analisis data dengan statistika deskriptif ini disajikan dalam bentuk tabel dan/atau diagram agar lebih mudah diinterpretasikan.

\section{HASIL PENELITIAN}

\section{Kondisi Awal Aktivitas Pembelajaran}

Berdasarkan hasil refleksi awal melalui evaluasi diri pengalaman mengajar mata kuliah Keterampilan Membaca dan juga pengamatan awal yang dilakukan teman sejawat, dapat disimpulkan bahwa terdapat permasalahan yang cukup serius dalam praktik pembelajaran membaca. Dalam proses pembelajaran partisipasi mahasiswa masih sangat rendah. Sebagian besar mereka memberikan respon yang kurang meyakinkan dan lamban ketika mengerjakan tugas-tugas yang diberikan dosen. Hal ini

juga dimungkinkan oleh strategi yang digunakan dosen dalam proses pembelajaran kurang dapat memotivasi mahasiswa.

\section{Hasil Pelaksanaan Tindakan}




\section{a. Proses Peningkatan Kemampuan memahami Bacaan melalui Strategi Membaca Kolaboratif}

\section{1) Siklus Pertama}

\section{a) Perencanaan}

Peneliti merancang skenario tindakan penelitian ini yang termuat dalam RPP. Kegiatan tindakan pada siklus pertama ini bertujuan untuk membentuk kebiasaan membaca terarah melalui pengenalan penerapan strategi membaca kolaboratif.dan membentuk kemandirian mahasiswa dalam memahami makna secara keseluruhan dari sebuah teks yang dibacanya. Dengan terbentuknya kebiasaan membaca terarah dan kemandirian tersebut diharapkan tercapainya tujuan tindakan berupa peningkatan kemampuan mahasiswa dalam memahami bacaan,yaitu pemahaman pada tingkat evaluatif dan apresiatif.

Perencanaan kegiatan tindakan pembelajaran pada siklus pertama dilakukan terlebih dahulu dengan menyusun rencana pembelajaran dengan menerapkan strategi membaca kolaboratif, mempersiapkan materi atau teks bacaan, mempersiapkan format observasi/pengamatan aktivitas dosen dan mahasiswa, catatan harian mahasiswa, dan format wawancara.Pelaksanaan tindakan pada siklus pertama ini dilaksanakan selama tiga kali pertemuan.

\section{b) Pelaksanaan Tindakan dan Observasi}

Berdasarkan hasil pengamatan terhadap aktivitas dosen peneliti dalam tiap kali pertemuan pembelajaran selama siklus pertama, maka dapat dikatakan bahwa secara umum kinerja peneliti dalam menerapkan tindakan sudah optimal. Kinerja peneliti dari pertemuan ke pertemuan berikutnya yang cenderung konsisten optimal dalam melaksanakan tindakan, juga telah membawa kemajuan yang cukup berarti terhadap aktivitas mahasiswa.

Apabila dilihat secara kualitatif, hingga akhir siklus terpantau peserta kuliah berpartisipasi dan terlibat aktif selama proses pembelajaran. Namun, secara kuantitatif rata-rata dari ketiga pertemuan yang dilaksanakan pada siklus pertama ini belum mencapai standar yang ditetapkan terkait dengan proses pembelajaran, yakni baru 
mencapai angka 64,72\%.

Hasil tes untuk kedua indicator yang diperoleh pada siklus pertama sudah menunjukan adanya peningkatan dibandingkan dengan hasil belajar mahasiswa yang diperoleh pada tes awal. Jika pada tes awal kemampuan mahasiswa dalam memahami bacaan hanya mendapatkan nilai rata-rata 44,85, maka setelah dilaksanakan tindakan selama satu siklus nilai rata-rata mahasiswa meningkat menjadi 56,85. Namun, angka tersebut belum mampu mencapai target yang telah ditetapkan.

Berdasarkan paparan di atas, temuan-temuan penelitian pada siklus pertama penelitian tindakan ini adalah sebagai berikut.

1. Kinerja peneliti dalam melaksanakan tindakan dalam proses pembelajaran sudah optimal, artinya pembelajaran membaca dengan menggunakan strategi membaca kolaboratif berjalan sesuai dengan rencana.

2. Kinerja mahasiswa selama proses pembelajaran pada silkus pertama ini berdasarkan standar yang diharapkan belum terpenuhi.

3. Data yang terhimpun melalui catatan harian dan wawancara dari mahasiswa menunjukan adanya kecenderungan respon positif dari masing-masing pertemuan.

4. Hasil belajar yang dijaring melalui tes kemampuan memahami bacaan pada akhir siklus pertama, yakni pertemuan keempat belum sesuai dengan harapan. Target 75\% mahasiswa tuntas belajar belum berhasil tercapai. Untuk siklus pertama ini mahasiswa yang dapat dikatakan tuntas belajar baru mencapai angka 71,87\%.

\section{c) Refleksi}

Sehubungan dengan kriteria keberhasilan pelaksanaan tindakan dalam penelitian ini, maka pada siklus pertama belum ada standar yang terpenuhi baik yang berkaitan dengan proses pembelajaran maupun hasil belajar. Selanjutnya, sesuai dengan rencana semula, pelaksanaan tindakan akan dilanjutkan ke siklus berikutnya dengan penyempurnaan atas kekurangan-kekurangan dan penyimpangan yang ditemui selama pelaksanaan tindakan pada siklus pertama.

\section{2) Siklus Kedua}

\section{a) Perencanaan}


Siklus kedua berlangsung berdasarkan rencana kegiatan tindakan yang disusun berdasarkan hasil temuan dan kondisi alami proses pembelajaran pada siklus pertama. Perencanaan kegiatan tindakan juga dituangkan dalam bentuk rencana pelaksanaan pembelajaran.Tujuan dilaksanakan siklus kedua ini adalah memantapkan kemampuan mahasiswa dalam memahami teks bacaan secara kelompok maupun individual dengan menggunakan strategi membaca kolaboratif. Kemampuan memahami bacaan yang akan dicapai dalam tindakan siklus kedua ini juga dirumuskan dalam dua aspek kemampuan pemahaman yaitu pemahaman pada tingkat evaluatif dan pemahaman apresiatif. Pada pelaksanaan siklus kedua ini lebih ditekankan pada pembimbingan mahasiswa dalam membuat pertanyaan bacaan terkait dengan pengukuran pemahaman pada tingkat evaluatif dan apresiatif ini.

\section{b) Pelaksanaan Tindakan dan Observasi}

Tindakan penelitian pada siklus kedua juga dilaksanakan dalam tiga kali pertemuan. Berdasarkan hasil pengamatan terhadap aktivitas dosen peneliti selama proses pembelajaran, maka dapat dikatakan bahwa secara umum memperlihatkan konsistensi, tetap optimal. Apabila dilihat dari aspek perilaku mahasiswa, maka aktivitas mahasiswa juga mengalami kemajuan dari pertemuan ke pertemuan. Hal ini ditandai dengan nilai yang diberikan oleh sejawat kolaborator terhadap aktivitas/kinerja mahasiswa meningkat. Rata-rata kinerja/aktivitas mahasiswa selama proses pembelajaran mencapai angka $82,15 \%$.

Informasi yang terjaring melalui catatan harian mahasiswa, juga menunjukkan perubahan ke arah yang lebih baik sejak awal pembelajaran sebagai dampak diterapkannya tindakan.Sebagian besar mahasiswa mengekspresikan respon simpatik terhadap pelaksanaan pembelajaran.Sementara itu, hasil wawancara yang dilakukan oleh sejawat kolaborator terhadap mahasiswa menguatkan informasi yang terjaring melalui catatan harian.

Hasil belajar yang diperoleh pada pelaksanaan siklus kedua juga sudah

menunjukan peningkatan. Jika pada siklus pertama kemampuan mahasiswa dalam memahami bacaan baru mencapai nilai rata-rata 56,85, maka setelah dilaksanakan 
siklus kedua meningkat menjadi 68,9. Apabila dilihat dari persentase keberhasilan mahasiswa yang dikatakan tuntas dalam memahami bacaan hanya sebanyak $71,87 \%$ dan meningkat pada siklus kedua sebanyak $82,15 \%$.

\section{c) Refleksi}

Pada tahap ini dosen peneliti dan sejawat kolaborator mendiskusikan temuantemuan yang diperoleh pada siklus kedua ini. Sehubungan dengan kriteria keberhasilan pelaksanaan tindakan yang ditetapkan dalam penelitian ini, maka pada siklus kedua, standar yang ditetapkan sudah terpenuhi baik yang berkaitan dengan proses pembelajaran maupun hasil belajar. Hal ini ditandai dengan nilai yang diberikan oleh sejawat kolaborator terhadap aktivitas/kinerja mahasiswa selama proses pembelajaran memperoleh rata-rata $82,15 \%$. Begitu juga halnya dengan hasil belajar memahami bacaan mahasiswa. Mahasiswa yang dikatakan tuntas dalam belajar sudah mencapai $82,15 \%$. Berdasarkan temuan penelitian pada siklus kedua ini, maka tindakan tidak perlu lagi dilanjutkan ke siklus berikutnya, karena kriteria keberhasilan tindakan sudah tercapai.

\section{b. Hasil Peningkatan Kemampuan memahami Bacaan melalui Strategi Membaca Kolaboratif}

Hasil tes kemampuan memahami bacaan mahasiswa setelah menggunakan strategi membaca kolaboratif pada akhir siklus pertama dapat dilihat dari dua aspek kemampuan pemahaman yakni pemahaman evaluatif dan pemahaman apresiatif. Pada pemahaman evaluatif menunjukkan bahwa mayoritas mahasiswa 20 orang (62.5\%) sudah mempunyai kemampuan baik, yakni memperoleh skor dengan rentangan antara 66 sampai 80, bahkan satu orang (3.12\%) sudah berada pada predikat sangat baik. Mahasiswa yang mendapatkan predikat cukup berjumlah 9 orang (28.12\%) dan mahasiswa yang memperoleh predikat kurang berjumlah 2 orang $(6.25 \%)$.

Pada tingkat pemahaman apresiatif, mahasiswa yang memperoleh predikat sangat baik hanya 1 orang (3.12\%) dengan nilai di atas 80., sedangkan mahasiswa yang mempunyai kemampuan baik, yakni memperoleh skor dengan rentangan antara 66 sampai 80 berjumlah 17 orang (53.12\%). Mahasiswa yang mendapatkan predikat cukup 
berjumlah 5 orang (15.62\%) dan mahasiswa yang memperoleh predikat kurang berjumlah 2 orang $(6.25 \%)$ dan tidak ada yang mendapatkan predikat sangat kurang.

Apabila dibandingkan dengan kemampuan awal mahasiswa yang diperoleh dari tes awal ke siklus pertama telah terjadi peningkatan. Jika pada tes awal diperoleh nilai rata-rata 44,85 terjadi peningkatan pada siklus pertama menjadi 56,85. Namun, hasil yang dicapai belum lagi mencapai standar yang ditetapkan.

Pada akhir siklus kedua juga telah dilaksanakan tes kemampuan memahami bacaan mahasiswa. Hasil tes juga dilihat dari aspek kemampuan pemahaman evaluatif dan apresiatif. Pemahaman evaluatif menunjukkan bahwa mayoritas mahasiswa, yakni 22 orang $(68,75 \%)$ mempunyai kemampuan baik, dengan perolehan skor nilai antara 66 sampai 80 , bahkan 9 orang $(28,12 \%)$ sudah berada pada predikat sangat baik, dengan perolehan nilai di atas 80 . Sisanya yang satu orang $(3,12 \%)$ mendapatkan predikat cukup dengan rentangan nilai antara 56 sampai 65 . Hal ini merupakan capaian yang luar biasa.

Pada tingkat pemahaman apresiatif, mayoritas mahasiswa juga memperoleh nilai pada rentangan antara 66 sampai 80, yakni 23 orang $(71,87 \%)$ dengan predikat baik. Dua orang $(6,25 \%)$ mahasiswa memperoleh nilai di atas 80 dengan predikat sangat baik. Mahasiswa yang mendapatkan predikat cukup berjumlah 4 orang $(12,5 \%)$ dengan perolehan nilai antara 56 sampai 65. Sedangkan mahasiswa yang memperoleh predikat kurang berjumlah 3 orang $(9,4 \%)$ dan tidak ada yang mendapatkan predikat sangat kurang. Jika pada siklus pertama mahasiswa yang tuntas belajar baru mencapai 71,87\% naik menjadi $82,15 \%$ pada siklus kedua.

\section{PEMBAHASAN}

\section{Proses Pembelajaran Memahami Bacaan melalui Strategi Membaca Kolaboratif}

Membaca merupakan kegiatan sehari-hari yang dilakukan oleh setiap orang saat ini.Seseorang akan mendapatkan pemahaman atas apa yang dibaca manakala ia dapat memadukan segala informasi yang telah ada pada dirinya sebelumnya 
(pengetahuan/pengalamannya) dengan segala informasi yang baru ia dapatkan dari sebuah teks. Dalam membaca, kemampuan dalam memahami teks merupakan hal yang penting. Adapun ranah yang dituju dalam upaya peningkatan kemampuan memahami bacaan ini mencakup tingkatan pemahaman pada tingkat evaluatif dan pemahaman apresiatif.

Patricia (1989:34) menyatakan bahwa arah rancangan tujuan belajar pada umumnya meliputi kemampuan kognitif, afektif, maupun psikomotorik. Tujuan tindakan pembelajaran dalam konteks penelitian ini berupa pemahaman isi bacaan merupakan aspek kemampuan kognitif, kemampuan proses pemahaman itu sendiri sebagai ranah psikomotor, sedangkan pembentukan kebiasaan belajar berbasis kolaborasi sebagai kemampuan afektif. Rancangan kegiatan belajar yang dirumuskan dalam rencana pembelajaran bagi tindakan peningkatan pemahaman bacaan ini telah dirancang sesuai dengan tahapan-tahapan kegiatan dalam strategi membaca kolaboratif. Merujuk pada pandangan Janette (2010:32) dalam merancang kegiatan membaca kolaboratif, (1) hendaknya seorang pengajar mengikuti rangkaian tahapan-tahapan strategi membaca kolaboratif dan ini menjadi strategi acuan dalam melakukan tindakan peningkatan pemahaman bacaan bagi pelajar dalam konteks penelitian ini. (2) Kegiatan belajar dibagi pada tiga tahapan, yaitu sebelum membaca (before reading), selama membaca (during reading), dan setelah membaca (after reading).

Selama menggunakan strategi membaca kolaboratif dalam pembelajaran membaca, partisipasi dan keterlibatan mahasiswa meningkat seiring meningkatnya kemunculan perilaku yang teridentifikasi selama proses pembelajaran berlangsung. Perilaku-perilaku yang dinilai oleh sejawat kolaborator telah mendongkrak partisipasi dan keterlibatan mahasiswa, di antaranya spontan merespon tugas/aktivitas pembelajaran, aktif dalam pelaksanaan diskusi, punya tanggung jawab serta mampu bekerjasama dalam kelompok, menyelesaikan tugas tepat waktu, dan serius/antusias dalam kerja kelompok. Kemudahan yang dirasakan oleh peserta antara lain tercermin dalam ungkapan seorang mahasiswa (P.9) pada catatan harian berikut: 'Kali keempat saya belajar CSR. Saya sudah paham langkah-langkahnya.Saya bisa berbagi pendapat 
lagi dengan teman-teman kelompok.Kelompoknya seru.Saya sudah mulai bisa membuat sintesis bacaan. Hal ini senada dengan yang dikemukakan oleh Timothy (2004:203) bahwa dalam pembelajaran kolaborasi akan terjadi pertukaran aktif ide-ide dalam kelompok-kelompok kecil sehingga akan meningkatkan minat di antara peserta dan juga mempromosikan berpikir kritis siswa dalam belajar.

\section{Hasil Peningkatan Kemampuan Memahami Bacaan melalui Strategi Membaca Kolaboratif}

Berdasarkan data kuantitatif yang diperoleh mulai dari pratindakan sampai dengan akhir penerapan strategi membaca kolaboratif dalam pembelajaran memahami bacaan menunjukkan adanya peningkatan kemampuan pemahaman bacaan mahasiswa. Dibandingkan dengan kondisi pratindakan, maka telah terjadi lonjakan yang luar biasa dalam kemampuan memahami bacaan mahasiswa yang diajarkan setelah dilaksanakan tindakan. Sebelum dilaksanakan tindakan pembelajaran menggunakan strategi membaca kolaboratif, hanya ada dua orang (6.24\%) mahasiswa yang mencapai nilai kategori baik. Rata-rata nilai hasil belajar mereka hanya sebesar 44,85. Pada siklus pertama, mahasiswa yang dikategorikan mendapatkan nilai baik yang diajarkan menggunakan strategi membaca kolaboratif telah mencapai 34.4\% dari keseluruhan jumlah peserta kuliah dengan perolehan nilai rata-rata 56,85. Perolehan nilai pada siklus kedua semakin meningkat dengan rata-rata nilai 68,9.

Berdasarkan hasil penelitian, membuktikan bahwa penerapan strategi yang dipilih dalam tindakan ini yakni strategi membaca kolaboratif telah mampu meningkatkan kemampuan memahami bacaan mahasiswa terutama pada tingkat pemahaman evaluatif dan apresiatif. Namun, dalam penelitian ini terdapat keterbatasan, di antaranya peneliti pelaksana tidak berkesempatan menjadi pengamat, meskipun sejak awal disadari bahwa dalam penelitian tindakan setiap anggota tim peneliti memiliki keterlibatan sepadan dan upaya untuk memperkecil resiko bias dapat dilakukan di antaranya dengan berganti peran. Ada baiknya peneliti pelaksana mengambil peran melakukan pengamatan atas pelaksanaan tindakan yang telah disepakati bersama. Namun demikian, karena hal ini tidak termasuk kesepakatan yang dijalin sejak awal di 
dalam kolaborasi tim masalah ketidaksiapan sejawat kolaborator dan jumlah anggota tim yang hanya terdiri dari dua orang menyebabkan hal ini tidak terealisir.

\section{SIMPULAN}

Penerapan strategi membaca kolaboratif dalam pembelajaran memahami bacaan secara nyata telah meningkatkan keterlibatan mahasiswa. Keterlibatan dalam pembelajaran mereka meningkat seiring dengan teridentifikasinya beberapa perilaku secara menonjol selama pembelajaran berlangsung, seperti merespon tugas secara spontan, aktif dalam diskusi, bisa bekerjasama, punya tanggung jawab, serius/antusias dalam pelaksanaan perkuliahan, serta menyelesaikan tugas tepat waktu. Tugas dan kegiatan perkuliahan yang dikemas di dalam strategi membaca kolaboratif yang diterapkan telah mampu membuat mahasiswa memahami bacaan dengan langkahlangkah yang sistematis dan terarah, sebagaimana tersurat melalui diary. Respon positif mahasiswa terutama karena pembelajaran berlangsung secara menyenangkan/mengasyikan dan memberi wawasan baru sebagaimana terungkap melalui catatan harian dan hasil wawancara.

Aktivitas mahasiswa yang meningkat setelah diterapkannya strategi membaca kolaboratif juga diikuti dengan meningkatnya kemampuan memahami bacaan mereka. Hasil yang didapat bisa disimpulkan bahwa kedua indikator yang dilihat dalam penelitian ini semua hasilnya meningkat mulai dari prasiklus, siklus pertama, dan siklus kedua. Untuk indikator pertama yakni pemahaman pada tingkat evaluatif nilai pada prasiklus 47,8 dan meningkat menjadi 60,3 pada siklus pertama, akhirnya menjadi 71,8 pada siklus kedua. Dalam hal ini mengalami peningkatan sebanyak 24\%. Untuk indikator kedua yakni pemahaman pada tingkat apresiatif perolehan nilai pada pratindakan 41,9 naik menjadi 53,4 pada siklus pertama dan naik lagi menjadi 66 pada siklus kedua. Indikator ini mengalami peningkatan sebanyak $24,1 \%$.

Berdasarkan simpulan penelitian dapat dimaknai bahwa proses pembelajaran dan hasil belajar mahasiswa dalam memahami bacaan dapat meningkat melalui penggunaan strategi membaca kolaboratif. Dengan kata lain, penerapan strategi membaca kolaboratif cukup efektif untuk meningkatkan kemampuan memahami bacaan. 


\section{DAFTAR PUSTAKA}

Barbara, J. Walker, Diagnostic Teaching of Reading: Techniques for Instruction and Assessment. New York: Macmillan Publishing Company, 1992.

Blachowicz dan Donna. Reading Comprehension: Strategies for Independent Learners.Second Edition. New York: The Guilford Press. 2008.

Brown, H. Douglas. Teaching by Principles: An Interactive Approach to Language Pedagogy. Longman. 2007.

Cristine, Nuttal. Teaching Reading Skill in a Foreign Language, New Edition. Great Britain: Heinemann, 1989.

Grabe, William. Reading in Second Language.Moving from Theory to Practice.New York: Cambridge University Press, 2009.

Klingner, J. Vaughn and J. Shumm.Collaborative Strategic Reading During School Studies in Heterogeneous Fourth-grade Classrooms. Elementary School Journal 99.3-21.

Patricia L, Smith, Tillman J. Ragan, Instructional Design. New York: John Wiley \& Sons, Inc, 2005.

Robert Burns. Introduction to Research Methods. Melbourne: Longman Australia Pty Ltd., 1994.

Robert, Timothy S. Collaborative Learning: Theory and Practice. Boston: Idea Group Publishing. 2004.

Smith, F. Reading. Melbourne: Cambridge University Press. 1999. 